\title{
Cotesia flavipes (CAM) (Hymenoptera: Braconidae) Supresses Immune Responses In Diatraea flavipennella (BOX) (Lepidoptera: Crambidae)
}

\author{
ELIANA M. DOS PASSOS ${ }^{1}$, VALÉRIA WANDERLEY-TEIXEIRA ${ }^{2}$, \\ EDMILSON J. MARQUES ${ }^{1}$, ÁLVARO A.C. TEIXEIRA ${ }^{2}$ and FÁBIO A. BRAYNER ${ }^{3}$ \\ ${ }^{1}$ Departamento de Agronomia, Universidade Federal Rural de Pernambuco, \\ Av. Dom Manoel de Medeiros, s/n, Dois Irmãos, 52171-900 Recife, PE, Brasil \\ ${ }^{2}$ Departamento de Morfologia e Fisiologia Animal, Universidade Federal Rural de Pernambuco, \\ Av. Dom Manoel de Medeiros, s/n, Dois Irmãos, 52171-900 Recife, PE, Brasil \\ ${ }^{3}$ Laboratório de Imunopatologia Keizo Asami/LIKA, Universidade Federal de Pernambuco, \\ Centro de Pesquisas Ageu Magalhães/CPqAM, Av. Moraes Rego, s/n, 50670-420 Recife, PE, Brasil \\ Manuscript received on October 13, 2013; accepted for publication on March 11, 2014
}

\begin{abstract}
The present research aimed to elucidate which aspects of immune responses in Diatraea flavipennella are suppressed by the parasitoid Cotesia flavipes, thus, ensuring parasitism success. We investigated the presence of apoptosis in fat body cells through the TUNEL technique. According to the results, reduced levels of nitric oxide and phenoloxidase activity were observed in larvae parasitized for three days, and reduced total number of hemocytes, after three and seven days. An increase in plasmatocytes and decrease in spherulocytes numbers were observed in the differential count on the third day of parasitism. The number of melanized microspheres in parasitized larvae was low and indicated less intense melanization. The ultrastructural analysis confirmed the immunosuppressive effect of $C$. flavipes on the encapsulation response of $D$. flavipennella because only the formation of hemocytes capsules, adhered to the microspheres' surface, was evidenced in non-parasitized caterpillars. The effect of parasitism was also recorded on the third day with the presence of hemocytes and apoptosis in fat body cells, including aspects of degeneration in the latter. We concluded that $C$. flavipes suppresses cellular and humoral immunological responses in D. flavipennella and drastically affects the host's fat tissue.
\end{abstract}

Key words: encapsulation, hemocytes, humoral response, parasitoid, Sugarcane Moth Borer (Diatraea saccharalis).

\section{INTRODUCTION}

Brazil is the world's largest producer of sugarcane, generating sugar and ethanol for domestic and international markets (MAPA 2012). However, the Diatraea sugarcane borer complex represents one of the main problems for this culture in worldwide regions of cultivation and the biological control of

Correspondence to: Eliana Maria dos Passos

E-mail: bisologa@hotmail.com sugarcane borers with Cotesia flavipes (Cameron) has been considered an efficient method (Pinto et al. 2006).

Diatraea saccharalis (Fabricius) and Diatraea flavipennella (Box) occur in Brazil (Mendonça 1996). The endo-parasitoid C. flavipes was cultivated in the laboratory on D. saccharalis and introduced in Brazil in mid-1974 for the control of both borer species. A reversal predominance of 
the sugarcane borer species occurred in the last 30 years in the state of Alagoas in Brazil (Freitas et al. 2006) showing D. flavipennella as currently the predominant species in northeastern Brazil.

The D. saccharalis and D. flavipennella borers feature bio-ecological similarities; however, the $C$. flavipes wasp does not demonstrate a preference between the two hosts and is equally able to locate the two species (Freitas et al. 2006, Silva et al. 2012). Nevertheless, upon acceptance by the host, the immature parasitoid faces a number of physiological challenges that may diminish its chances of survival and the host's immune defense mechanisms is the biggest challenge faced by the parasite (Edwards et al. 2001).

Encapsulation is the most used defense mechanism by hosts against foreign eggs or immature parasitoids; the hemocytes recognize eggs and immature parasitoids as intruders and form a capsule around them (Strand and Pech 1995). The deposition of melanin that occurs on the capsules, or on the intruder itself, is formed during the oxidation and polymerization of phenols by enzymes called phenoloxidases (Nappi et al. 1991, 1992, Beckage 1998). The cytotoxic molecules generated in this process include reactive oxygen species (ROI), nitrogen (RNS), and quinoids that are intermediates of melanin (Nappi and Ottaviani 2000). An increase in nitric oxide (NO) production occurs in immunoreactive hosts, which acts as the effector molecule in the interaction with reactive intermediates, triggering the cytotoxic activity used in the defense against invaders (Nappi et al. 2000).

The induction of apoptosis by the parasite in the tissues of the insect host is described as one of the means to manipulate the host and ensure the development of parasitoids (Nakamatsu and Tanaka 2003, Zhang et al. 2005, Asgari 2006, Rivers et al. 2007). In addition, apoptosis in hemocytes leads to the consequent reduction in these cells' number and interruption of the encapsulation response (Teramoto and Tanaka 2004, Luo and Pang 2006, Suzuki and Tanaka 2006, Richards and Dani 2007).
The understanding of the host-parasitoid interactions between $C$. flavipes and $D$. flavipennella has not been addressed in the literature. Therefore, the present study investigated the cellular and humoral responses and apoptosis in the fat body tissue triggered by $C$. flavipes parasitoids in the D. flavipennella host.

\section{MATERIALS AND METHODS}

The experiments were conducted at the Insect Pathology and Insect-Toxic Interaction Laboratories, Department of Agronomy, Rural Federal University of Pernambuco, and the Keizo Asami Immunopathology Laboratory-LIKA, Federal University of Pernambuco and Ageu Magalhães Research Center - CPqAM/ FIOCRUZ.

INSECTS

D. Alavipennella caterpillars were cultivated in laboratory conditions $\left(27 \pm 1{ }^{\circ} \mathrm{C}, 70 \%\right.$ of relative humidity, and $12 \mathrm{~h}$ photoperiod) with the Hansley and Hammond (1968) artificial diet modified by Araújo et al. (1985). The parasitoids were supplied in the pupal stage by the ASPLAN-PB (Association of sugarcane growers of Paraíba). Caterpillars of D. Alavipennella (sixth instar), $24 \mathrm{~h}$ old, were manually offered to female parasitoids to establish parasitism. In each bioassay, parasitized and nonparasitized caterpillars were individually isolated in plastic pots and fed an artificial diet.

ANALYSES OF THE LEVELS OF NITRIC OXIDE,

PHENOLOXIDASE, AND TOTAL PRoteIN IN THE HEMOLYMPH

The NO concentration was established based on the Griess reagent according to the manufacturer's protocol (Promega Corporation). Twenty microliters of hemolymph was diluted in $90 \mu \mathrm{L}$ of sulfanilamide (1\%) in $\mathrm{H}_{3} \mathrm{PO}_{4}(5 \%)$. The amount of nitrite $\left(\mathrm{NO}_{2}\right)$ in the samples was correlated with absorbance values obtained from the standard curve of sodium nitrite $\left(\mathrm{NaNO}_{2}\right)$.

The levels of phenoloxidase (PO) were determined using $10 \mu \mathrm{L}$ of hemolymph diluted in $100 \mu \mathrm{L}$ of $0.1 \mathrm{M}$ phosphate buffer at $\mathrm{pH} 7.2$ (PBS). 
Absorbance measurements relaying the PO activity on the substrate and L-3,4-dihidroxifenilalanine (L-DOPA) in PBS buffer were read in triplicates at one-minute intervals over the course of 31 minutes. Thus, the kinetic activity of PO per $\mu \mathrm{L}$ of hemolymph (Vmax, where one enzyme unit was defined based on the change of 0.001 in optical density at $490 \mathrm{~nm}$ per minute) was determined using the Gen 5 software.

The total protein concentration was determined in the samples by a colorimetric test using a commercial kit (Coomassie Plus Protein, Pierce Biotechnology) based on the Bradford test (1976) and bovine serum albumin (BSA) for the standard curve. The concentrations of NO, PO, and total protein were compared between non-parasitized and parasitized caterpillars in the period of zero days (4 h), three, and seven days to verify the response of these components at different time points after induction of parasitism. The data were evaluated by analysis of variance, transformed as needed in $\sqrt{ }(x+0.5)$, and the means were compared by the Tukey's test and/or the $t$ test at $5 \%$ probability.

\section{DifFERENTIAL AND TOTAL HEMOCYTE COUNTS}

To determine total counts, $5 \mu \mathrm{L}$ of hemolymph was mixed with $20 \mu \mathrm{L}$ of $0.1 \mathrm{M}$ sodium phosphate buffer at $\mathrm{pH} 7.2$ (PBS); a $10 \mu \mathrm{L}$ sample was used in a Neubauer Chamber to count the total number of hemocytes per microliter of hemolymph in the intervals between zero $(4 \mathrm{~h})$, one, three, five, seven, and nine days of parasitism. The differential count of hemocytes was performed using $5 \mu \mathrm{L}$ of hemolymph mixed with $5 \mu \mathrm{L}$ of PBS on a glass slide after being smeared, fixed in methanol (PA), and stained with Giemsa. The percentage of cell types was established in the intervals that showed differences in total hemocyte counts according to the methodology of Falleiros et al. (2003). Three hundred cells were counted in each repetition. The results from total and differential counts were evaluated by analysis of variance in a factorial scheme. The averages were compared by the $t$ test at $5 \%$ probability; the total counts and spherulocytes data were transformed in $\sqrt{ }(x+0.5)$.

\section{Melanization Test}

To verify the suppression ability of $C$. flavipes over the encapsulation response of $D$. flavipennella, DEAE Sephadex A-50 (Sigma) microspheres with diameters ranging from 40 to $120 \mu \mathrm{m}$ were suspended in PBS (0.1 M; pH 7.2) at a concentration of $20 \mathrm{mg} / \mathrm{mL}$. Fifteen microliters of this suspension was injected in $6^{\text {th }}$ instar, non-parasitized and parasitized caterpillars, on days 1 and 5. These intervals were established for the analysis of encapsulation before and after the hatching of the parasitoid larva and presence of teratocytes, respectively. The assessment was made under a stereoscopic microscope at $24 \mathrm{~h}$ after the injection. Fifteen repetitions were used in this bioassay, each repetition represented by one caterpillar in each studied time point, considering parasitized and non-parasitized caterpillars, and totaling 60 studied caterpillars. The count data from melanized spheres were compared by the Mann-Whitney U-test $(\mathrm{p}<0.05)$.

The ultrastructure analysis of these microspheres investigated whether or not the formation of layers of cells occurred. The microspheres were fixed in 2.5\% glutaraldehyde solution, $4 \%$ PFA, and $0.1 \mathrm{M}$ phosphate buffer at $\mathrm{pH} 7.2$, post-fixed in $2 \%$ osmium tetroxide $\left(\mathrm{OsO}_{4}\right)$, and processed for inclusion in EMBED812/Araldite resin (Electron Microscopy Sciences, Fort Washington, PA). Ultrathin sections were obtained in an ultramicrometer (Reichert Ultracut), contrasted in uranyl acetate for $1 \mathrm{~h}$ and lead citrate for $10 \mathrm{~min}$, and analyzed in a Zeiss EM109 microscope.

APOPTOSIS IN THE FAT BODY

Whole non-parasitized caterpillars at 3 and 9 days of parasitism were fixed in $10 \%$ buffered formalin, sectioned in the medium body region, and processed for inclusion in paraffin. The cuts were placed on silanized slides and submitted to the TUNNEL test according to the protocol in the ApopTag ${ }^{\circledR}$ Plus kit. 


\section{RESULTS}

Analysis of the LeVels of Nitric Oxide, Phenoloxidase, AND TOTAL PROTEIN IN THE HEMOLYMPH

The levels of NO in the hemolymph differed between parasitized and non-parasitized larvae on days 3 and 7 after the start of the experiment. A reduction in the levels of nitric oxide in parasitized caterpillars was observed 3 days after parasitism (Table I). The PO activity in the hemolymph of $D$. flavipennella was altered by the $C$. flavipes parasitism. Figure 1 shows changes in enzyme levels during 31 minutes and Figure 2 shows differences in the PO kinetic activity (Vmax). In both cases, a reduction in enzyme activity was evidenced in parasitized caterpillars,
TABLE I

Concentrations of nitric oxide $\left(\mu \mathrm{M}\right.$ of $\mathrm{NO}_{2}{ }^{-} / \mu \mathrm{L}$ of hemolymph) in Diatraea flavipennnella caterpillars that were non-parasitized and parasitized by Cotesia flavipes.

\begin{tabular}{cccc}
\hline Time & Parasitized & Non-parasitized & $t$-statistics \\
\hline $0^{\circ}$ Day & $8.7 \pm 1.02 \mathrm{Aa}$ & $10.1 \pm 0.89 \mathrm{Aa}$ & $-1.06^{0.3047}$ \\
$3^{\circ}$ Day & $5.4 \pm 0.26 \mathrm{Ab}$ & $9.4 \pm 0.93 \mathrm{Ba}$ & $-4.05^{0.0021}$ \\
$7^{\circ}$ Day & $10.7 \pm 1.16 \mathrm{Aa}$ & $7.2 \pm 0.90 \mathrm{Ba}$ & $2.27^{0.0353}$ \\
\hline Statistics $^{2}$ & $\mathrm{~F}_{2.29}=11.46^{\mathrm{P}=0.0002}$ & $\mathrm{~F}_{2.29}=2.81^{\mathrm{P}=0.0782}$ & \\
\hline
\end{tabular}

${ }^{1}$ Averages $( \pm \mathrm{EP})$ followed by the same uppercase letter in the same row do not differ by the $t$ test $(\mathrm{p}>0.05)$.

${ }^{2}$ Averages ( \pm EP) followed by the same lowercase letter in the same column do not differ by the Tukey's test $(p>0.05)$.
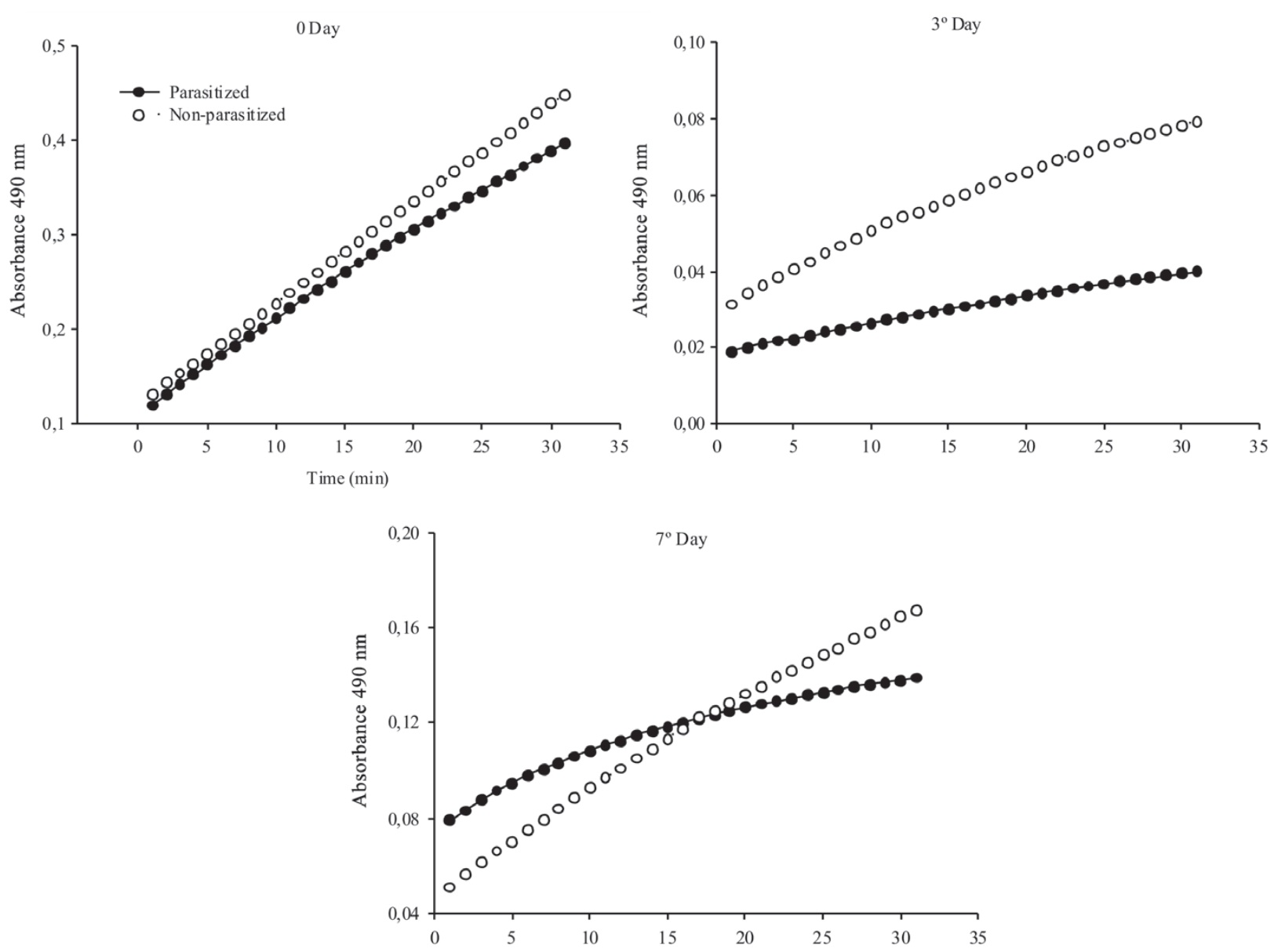

Figure 1 - Phenoloxidase activity, absorbance at $490 \mathrm{~nm}$ in different periods of evaluation in Diatraea flavipennella caterpillars that were non-parasitized and parasitized by Cotesia flavipes. 
after three days, compared with non-parasitized caterpillars. Significant reduction in the levels of total protein was observed in the hemolymph of $D$. flavipennella parasitized by C. flavipes at seven days after parasitism (Fig. 3).

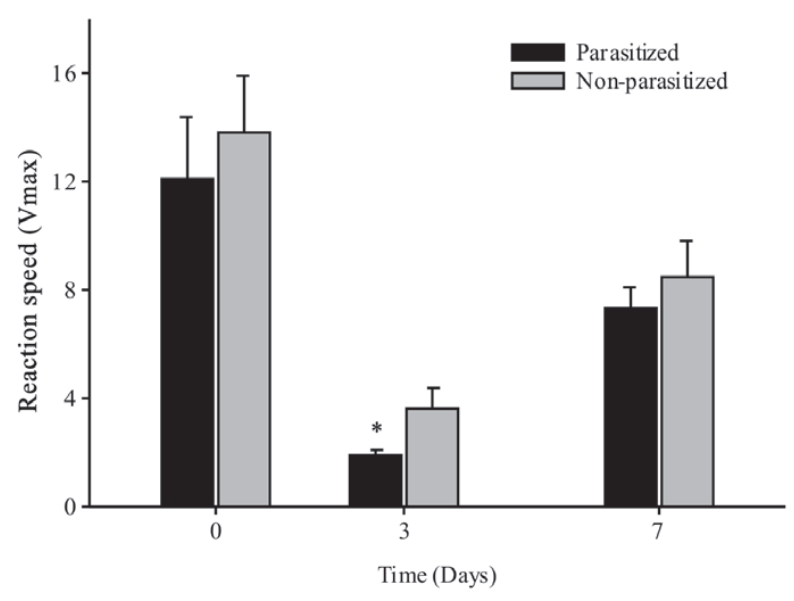

Figure 2 - Kinetic activity of phenoloxidase, reaction speed $(\Delta \mathrm{Abs} / \mathrm{min})$ in Diatraea flavipennella caterpillars that were non-parasitized and parasitized by Cotesia flavipes.

*Significant difference between treatments by the $t$ test $(\mathrm{p}<0.05)$.

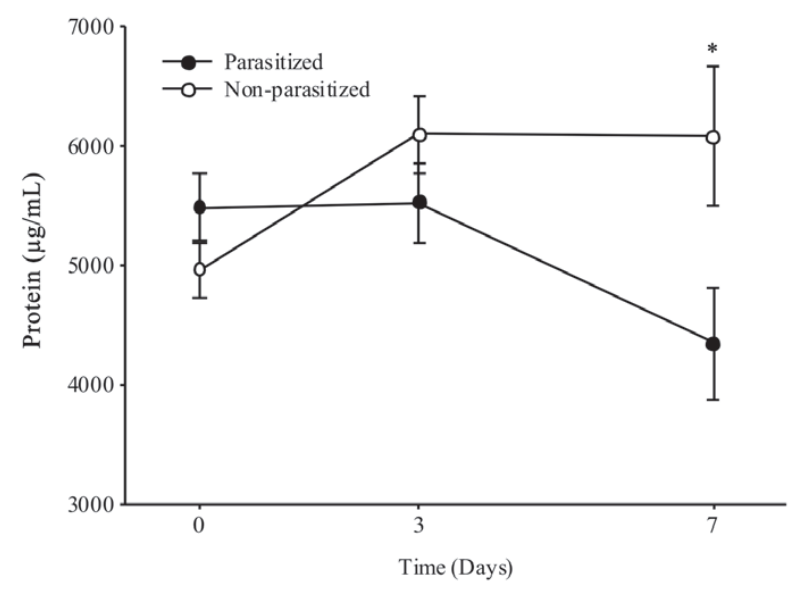

Figure 3 - Total protein concentration ( $\mu \mathrm{g} / \mathrm{mL}$ of hemolymph) in Diatraea flavipennella caterpillars that were non-parasitized and parasitized by Cotesia flavipes. *Significant difference between treatments by the $t$ test $(\mathrm{p}<0.05)$.

\section{Total AND DifFERENTIAL Hemocyte CounTS}

The hemocyte dynamics of $D$. Alavipennella was altered by $C$. flavipes parasitism $\left(\mathrm{F}_{11.83}=6.05\right.$; $\mathrm{p}<0.0001)$. Differences in the total number of hemocytes and variation in their amounts over time were observed between parasitized and nonparasitized caterpillars during the evaluated period $\left(\mathrm{F}_{1.83}=8.41 ; \mathrm{p}=0.0049\right)$ and tested treatments $\left(\mathrm{F}_{5.83}\right.$ $=9.52 ; \mathrm{p}<0.0001)$. However, the results showed that there was no interaction between time and treatment $\left(\mathrm{F}_{5.83}=2.11 ; \mathrm{p}=0.0738\right)$. A reduction in the total number of hemocytes in parasitized caterpillars was observed at three and seven days after exposure to parasitoids (Fig. 4). Among the types of observed hemocytes, plasmatocytes and spherulocytes were the most frequent, while prohemocytes, granulocytes, oenocytoids, and adipohemocytes occurred in proportions that were less than $5 \%$ at 3 days and $2 \%$ at 7 days post treatment. Therefore, only the average percentage of plasmatocytes and spherulocytes differed with different treatments; an increase in the number of plasmatocytes and reduction in spherulocytes were observed at 3 days of parasitism (Fig. 5).

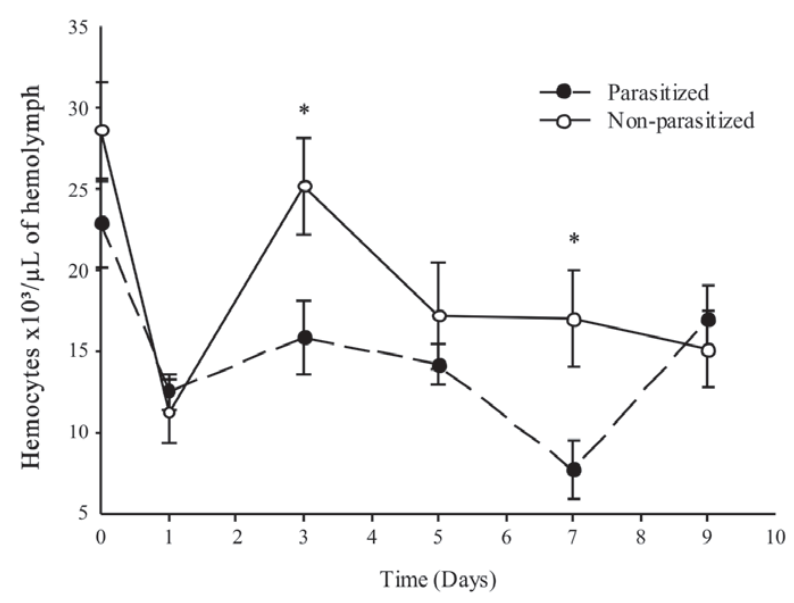

Figure 4 - Total number of hemocytes in Diatraea flavipennella caterpillars (average \pm EP) that were non-parasitized and parasitized by Cotesia flavipes. *Significant difference between treatments by the $t$ test $(\mathrm{p}<0.05)$.

\section{MELANIZATION TEST}

The stereomicroscopic analysis showed the presence of melanization of microspheres in nonparasitized and parasitized caterpillars, however, this reaction was more intense in non-parasitized caterpillars (Figs. 6A, 6B, and 6C). It was possible 


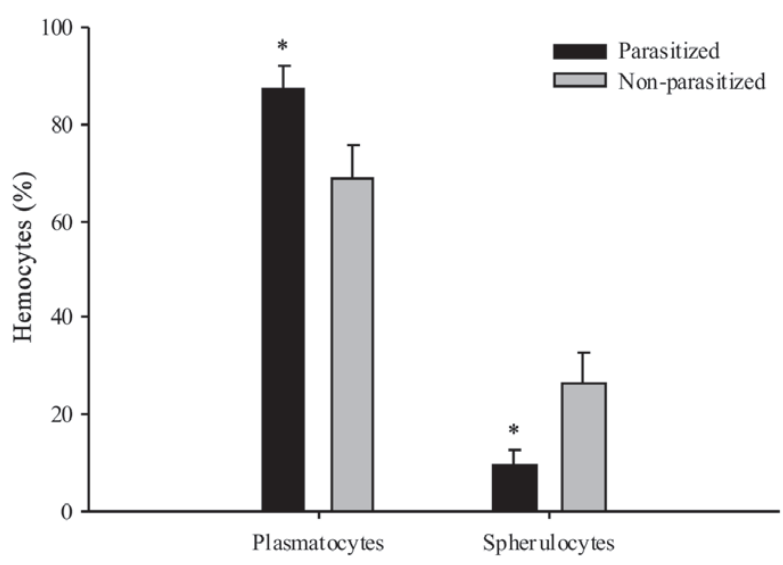

Figure 5 - Average ( \pm EP) of the differential counts (\%) of hemocytes in Diatraea flavipennella caterpillars that were non-parasitized and parasitized by Cotesia flavipes on the third day of parasitism. *Significant difference between treatments by the $t$ test $(\mathrm{p}<0.05)$. to observe the presence of parasitoid larvae in the hemocele of caterpillars at five days of parasitism (Fig. 6 D). The number of melanized microspheres in the two evaluated periods of parasitism, on the first and fifth day, differed between parasitized and non-parasitized caterpillars; a gradual reduction in this number was observed over time (Fig. 7).

\section{ENCAPSULATION TEST}

The ultrastructural analysis confirmed the immunosuppressive effect of the mechanisms used by the parasitoid C. flavipes to suppress cellular immune responses in $D$. flavipennella. The formation of layers of hemocytes, adhered to the surface of the microspheres forming a capsule, was revealed in the non-parasitized caterpillars on the first and fifth day.

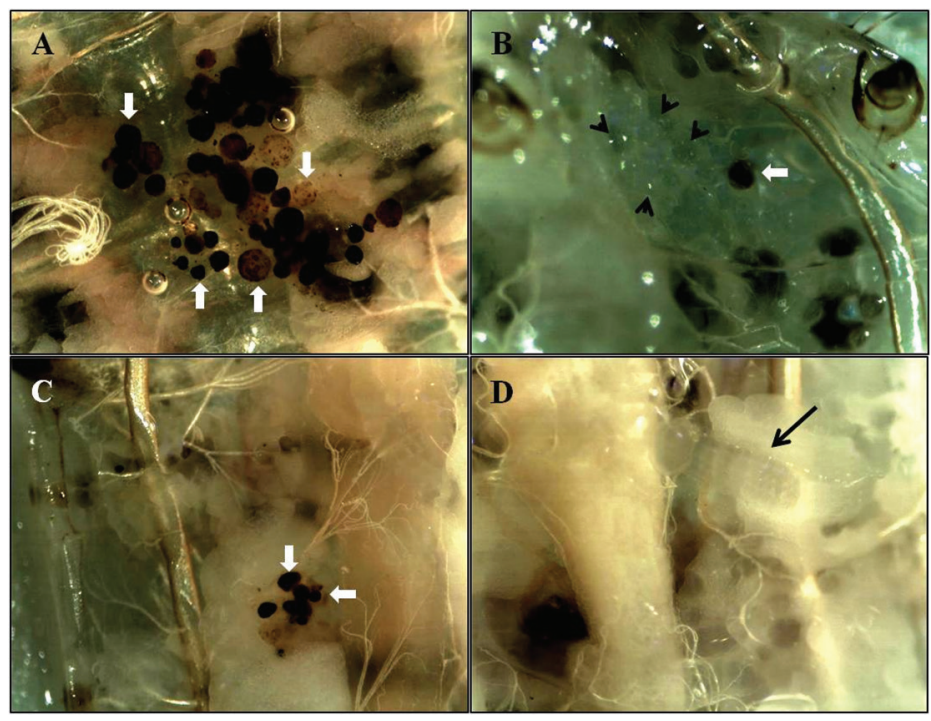

Figure 6 - Caterpillars of Diatraea flavipennella injected with microspheres. $\mathrm{A}$ and $\mathrm{C}$ represent non-parasitized (witness), and B and D represent parasitized on the first and fifth day after parasitism, respectively. Short arrow - non-melanized micro-sphere; thick arrow - melanized micro-sphere; long arrow - parasitoid larva. Bars $=100 \mu \mathrm{m}$.

This capsule was formed by plasmatocytes, which are cells with elongated morphology, extremely juxtaposed, and showing cytoplasmic projections (Fig. 8A, 8B, 9A, and 9B). Conversely, caterpillars injected with microspheres did not exhibit formation of capsules of hemocyctes around the foreign body at one and five days post injection. Granulocytes showing intense degranulation and occasional pyknotic nucleus, were the most frequently observed cells on the first day of parasitism; however, on the fifth day, these cells were infrequent and showed no degranulation. The presence of binucleated granulocytes was recorded (Fig. 8C, 8D, 8E, 8F, 9C, and 9D). Teratocytes were only evidenced on the 


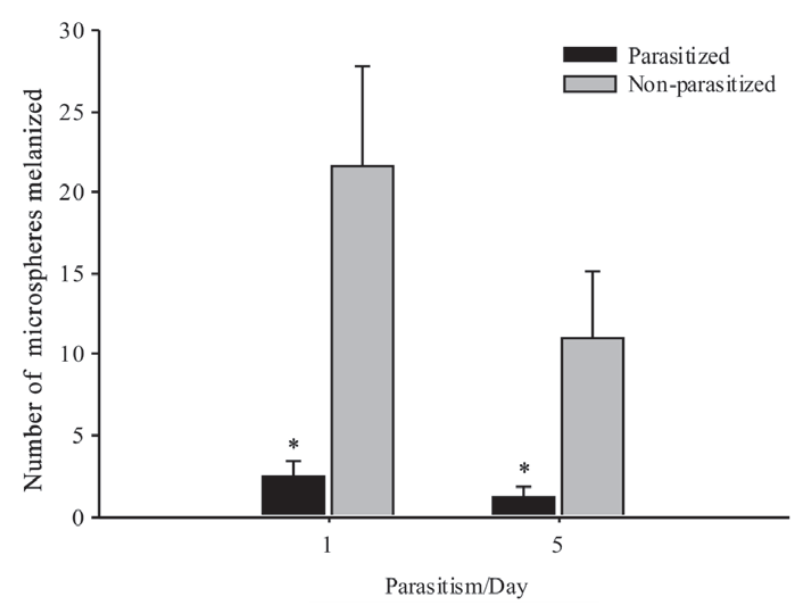

Figure 7 - Average ( \pm EP) of the microspheres (Sephadex) melanized by Diatraea flavipennella caterpillars that were non-parasitized and parasitized by Cotesia flavipes and evaluated after $24 \mathrm{~h}$ from injection. Significant differences between treatments $(*)$ and in the parasitized treatment $(* *)$ by the Mann-Whitney U-tests $(\mathrm{p}<0.05)$.

fifth day of parasitism showing elliptical format with microvilli and irregular and very euchromatic nucleus with heterochromatin areas. The presence of welldeveloped endoplasmic reticulum and vesicles were observed in the cytoplasm (Fig. 9C, 9E, and 9F).

\section{APOPTOSIS IN THE FAT BODY}

The presence of apoptotic nuclei was observed in the fat body of non-parasitized and parasitized caterpillars at 3 days after parasitism. In these, the labeling occurred in both fatty parietal body, just below the integument, and perivisceral fat body around the digestive tract. It is noteworthy that the labeling was more frequent in the fat body in parasitized larvae. The fat body also presented a degenerative aspect.

The presence of hemocytes near the parietal fat body that contained positively labeled nuclei was observed in parasitized caterpillars indicating its fragmentation (Figs. 10A, 10B, 10C, and 10D). The caterpillar's hemocele was primarily occupied by the parasitoid larvae at 9 days after parasitism; the fat body was basically restricted to a thin layer in the parietal region in which the presence of nuclei in apoptosis was not observed (Figs. 10E and 10F).

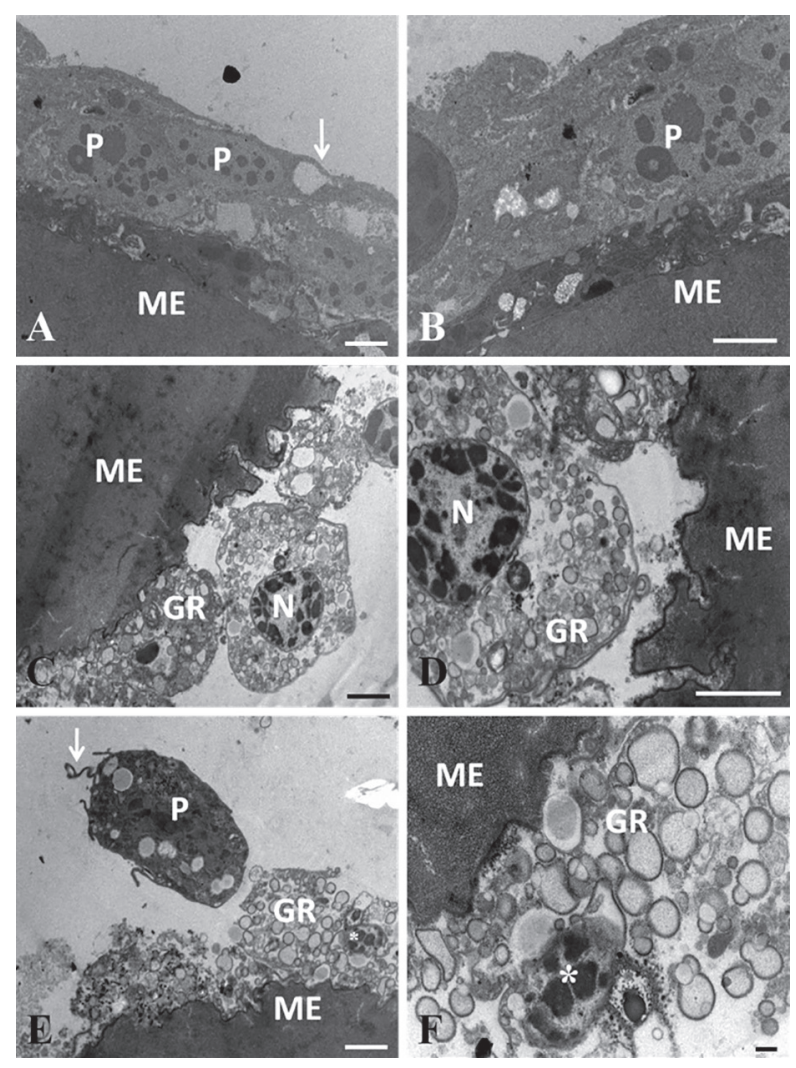

Figure 8 - Transmission eletromicrographes of microspheres collected from the hemocele of Diatraea flavipennella caterpillars that were non-parasitized (A and B) and at one day of parasitism by Cotesia flavipes (C, D, E, and F). ME - Microspheres, P - Plasmatocytes, GR - Granulocyte. Arrow Cytoplasmic projections, N - Nucleus and * Pyknotic nucleus. Bars $=1 \mu \mathrm{m}$.

\section{DISCUSSION}

The cellular and humoral responses and occurrence of apoptosis in the fat body nutritional reserve tissue in D. falvipennella that were triggered by $C$. flavipes parasitism, were investigated.

Parasitism of lepidoptera larvae by endoparasitoids is usually associated with suppression of humoral and cellular immunity in the host (Bae and Kim 2004). However, the role of each one of the components used by the parasitoid to manipulate physiological aspects and suppress the host's defense varies according to the species involved in the host-parasitoid interaction (Asgari and Rivers 2011). The results of this study indicate 


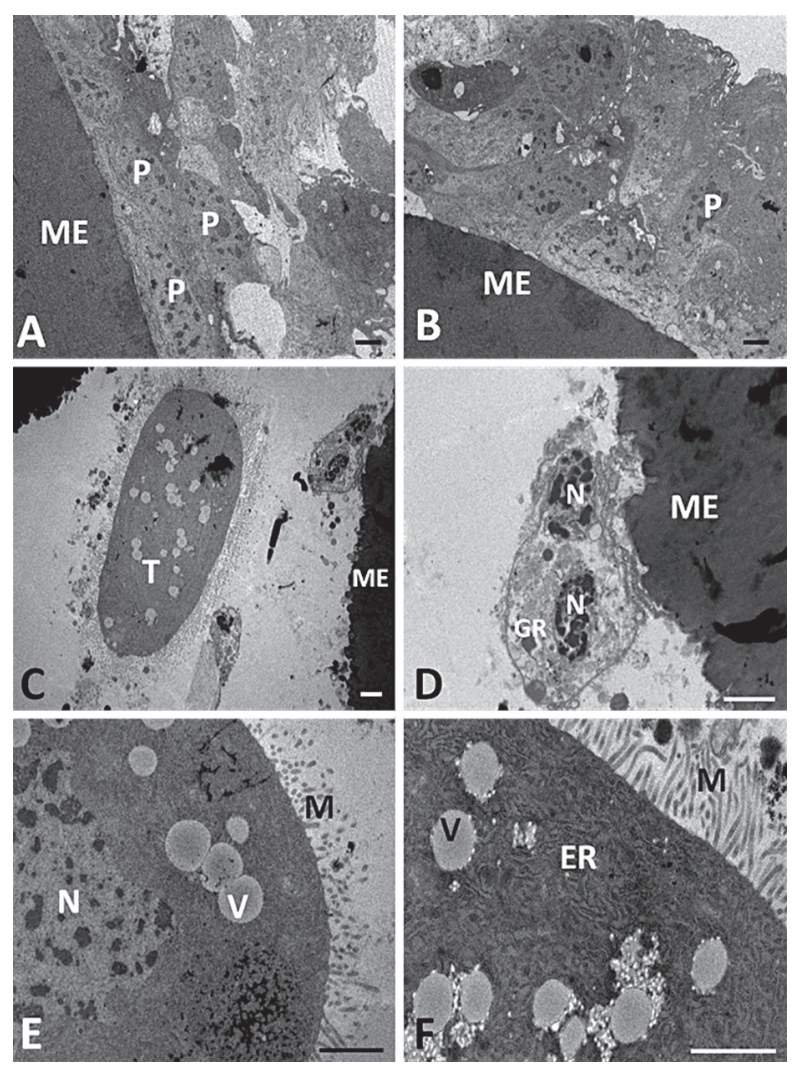

Figure 9 - Transmission eletromicrographes of microspheres collected from the hemocele of Diatraea flavipennella caterpillars that were non-parasitized (A and B) at 5 days of parasitism by Cotesia flavipes (C, D, E, and F). ME - micro-sphere, PPlasmatocytes, T - Teratocytes, N - nucleus, M - Microvilli, $\mathrm{V}$ - Vesicle, ER - endoplasmic reticulum. Bars $=1 \mu \mathrm{m}$.

that the endo-parasitoid $C$. flavipes ensures its development in D. flavipennella by suppressing the host's cellular and humoral responses and triggering apoptosis and degradation in the fat body.

The interference in the levels of NO, PO activation, and hemocyte dynamics was only evidenced from the third day of parasitism. This fact is likely due to the release of teratocytes from the parasitoid's egg, which occurs 2 to 3 days after parasitism, as observed in D. saccharalis when parasitized by C. flavipes (Conte etal. 1995). However, the ability of the parasitized host to encapsulate microspheres was affected at $24 \mathrm{~h}$ after parasitism and suppressed after 5 days of parasitism. According to the literature, the suppression of melanization and
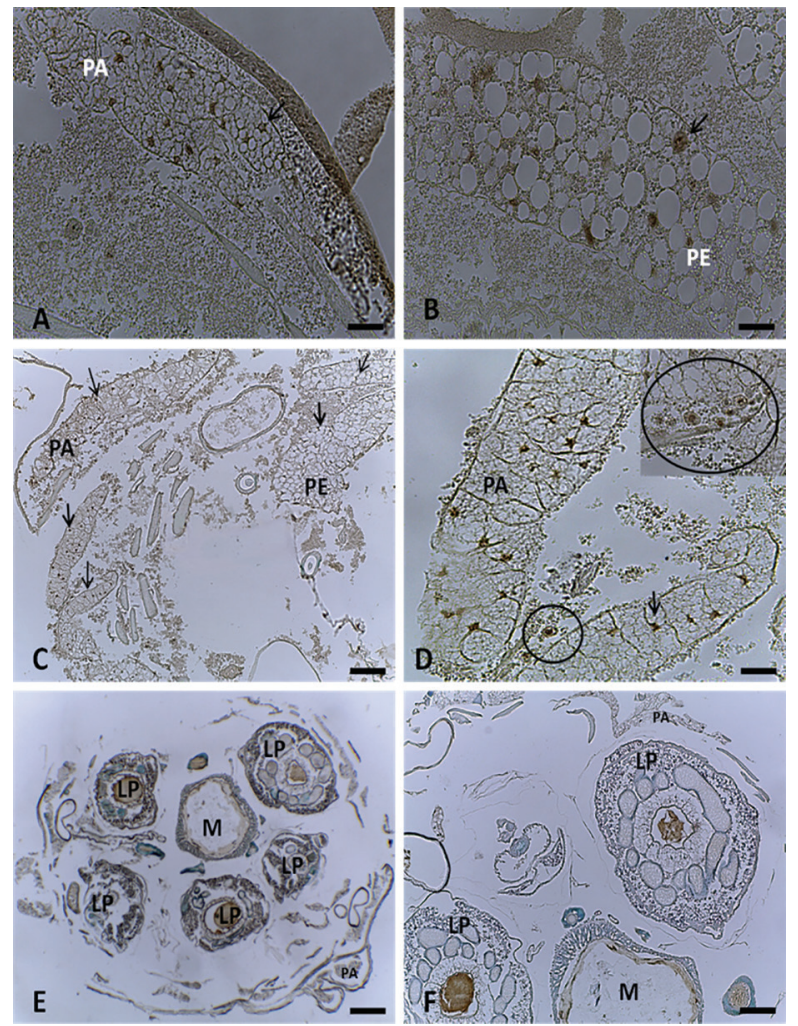

Figure 10 - Fat body of Diatraea flavipennella non-parasitized (A and B) at 3 days (C and D) and 9 days (E and F) of parasitism by Cotesia flavipes. Arrows - Indicate labeling of apoptotic points in the fatty tissue; Circles - in the hemocytes, PA Parietal fat body, PE - Perivisceral fat body, $\mathrm{LP}=$ Parasitoid larvae, $\mathrm{M}$ - Mesenteron. (A, B, and F Bars $=50 \mu \mathrm{m}$; $\mathrm{C}$ Bar $=$ $100 \mu \mathrm{m}$, and $\mathrm{E}$ Bar $=200 \mu \mathrm{m})$.

encapsulation occurs on the first day of parasitism because of maternal immunosuppressive factors such as ovarian proteins, poison, and poly DNA virus. However, this suppression becomes more pronounced with the presence of immunosuppressive factors of embryonic origin, such as teratocytes from the parasitoid larva (Dahlman and Vinson 1993, Strand and Pech 1995, Bae and Kim 2004, Beckage and Gelman 2004), which explains the parasitism behavior of $C$. flavipes in D. flavipennella.

Increased production of NO occurs in imunoreactive hosts when $\mathrm{NO}$ acts as an effector molecule in the interaction with intermediate reactives triggering the cytotoxic activity against invaders (Nappi et al. 2000). In addition, NO acts as a signaling molecule 
recruiting hemocytes to the site of infection (Foley and O' Farel 2003, Nappi 2010). The production of NO was suppressed by the parasitoid, and a reduction in PO activity was observed, also due to parasitism, which has been reported for other species (Bae and Kim 2004, Mabiala-Moundoungou et al. 2010). Mahmoud et al. (2012) have shown that $C$. flavipes inhibits the enzymatic activity of PO in $D$. saccharalis. The reduction in this enzyme's activity is accompanied by a reduction in melanization, where the melanin, which is the main product of the prophenoloxidase (proPO) system, stops acting on the invader (Carton and Nappi 1997, Lavine and Beckage 1995, Bae and Kim 2004). According to Ashida and Brey (1998), the pro PO system can still be involved in the production of opsonins, and thereby, the signaling of the presence of a foreign body could be compromised. Thus, the interaction between humoral and cellular immune factors is evidenced when hemocytes are important producers of humoral molecules, and when humoral factors affect the function of hemocytes, such as NO and $\mathrm{PO}$, in the recruitment of these cells (Lavine and Strand 2002, Ribeiro and Brehélin 2006).

The most direct way to prevent encapsulation, which is the expected immune response against parasitism, is to destroy, remove, or alter the behavior of hemocytes that mediate encapsulation (Strand and Pecch 1995). This was observed in this study through the reduction in the total number of hemocytes; similar results have been reported for other insects after parasitism (Alleyne and Wiedenmann 2001, Ibrahim and Kim 2006, Mabiala-Moundoungou et al. 2010).

Plasmatocytes and granulocytes are hemocytes that most actively participate in encapsulation response (Ibrahim and Kim 2006). An increase in the number of plasmatocytes and a reduction in the number of spherulocytes was observed in the differential count of hemocytes performed in this study at 3 days of parasitism. Ling and Yu (2006) also found spherulocytes participating in the encapsulation of a foreign body in Maduca sexta (Linnaeus). Moreover, according to Sass et al. (1994), these hemocytes are involved in the transport of cuticular components.

Microspheres were injected in caterpillars to ensure the immunosuppressant effect of $C$. flavipes on the immune response for encapsulation in $D$. flavipennella, however, few melanized microspheres were observed in the parasitized caterpillars. Studies have shown a deficiency in melanization and nodule formation around foreign particles, or even around microorganisms, due to host's immune system impairment in the presence of immunosuppressive factors in parasitoids (Er et al. 2010, Mahmoud et al. 2011, Mahmoud et al. 2012). The melanization and encapsulation of microspheres in D. saccharalis were suppressed by the C. flavipes parasitoid; however, this same parasitoid had its eggs encapsulated and melanized by hemocytes when parasitizing a host that was considered "refractory" such as $M$. sexta (Rodrigues-Pérez et al. 2005, Mahmoud et al. 2011).

The compromised immune response in parasitized caterpillars was confirmed through electromicrographies showing only one attempt of encapsulation. Granulocytes are the first cells to recognize a foreign body in the process of encapsulation, fixing on it, and releasing their contents to form an adhesive matrix on the target's surface, which induces the deposition of multiple layers of plasmatocytes (Beckage 2006). Therefore, the success in encapsulation depends on the recognition of the invader and presence of sufficiently large amounts of hemocytes for the formation of the capsule (Strand and Pech 1995, Lavine and Strand 2002, Carton et al. 2005).

The ineffectiveness in the encapsulation process due to a reduction in the number of circulating hemocytes has been attributed to the occurrence of apoptosis in hemocytes and histolysis in the hematopoietic organ (Teramoto and Tanaka 2004, Luo and Pang 2006, Suzuki and Tanaka 2006, Richards and Dani 2007). Some hemocytes with apoptotic nucleus were visualized in parasitized caterpillars at 3 
days of parasitism. However, due to the small sample size in this study, we cannot assign the encapsulation failure to apoptosis of hemocytes in D. flavipennella parasitized by $C$. flavipes.

In this study, the presence of apoptotic cells in the fat body of non-parasitized and parasitized caterpillars was observed at 3 days after parasitism. However, a differentiation in the structural aspect of the fatty tissue was observed, which, when parasitized, is shown as less developed and with degenerated aspect. According to Teramoto and Tanaka (2004), morphological changes in the fat body such as severely stunted nucleus, result from parasitism. In nonparasitized caterpillars, apoptosis might result from a proximity to the pupal period because autophagic degradation of organs, during larval metamorphosis, occurs in Lepidoptera (Müller et al. 2004).

Hence, it can be concluded that $C$. flavipes suppresses the cellular and humoral immune response in D. Alavipennella and drastically affects the fat body, which is a nutrient reserve tissue. The results of this study contribute to the understanding of the mechanisms involved in host-parasitoid interactions between $C$. flavipes and $D$. flavipennella.

\section{RESUMO}

A presente pesquisa visou elucidar quais aspectos da resposta imune em Diatraea flavipennella ão suprimidos pelo parasitoide Cotesia flavipes, para garantir o sucesso do parasitismo. Investigou-se a presença de células em apoptose no corpo gorduroso pela técnica de TUNEL. De acordo com os resultados verificou-se redução nos níveis de oxido nítrico e na atividade da fenoloxidase nas lagartas parasitadas, aos três dias, e redução do número total de hemócitos aos três e sete dias. Na contagem diferencial, observou-se aumento no número de plasmatócitos e redução de esferulócitos, no terceiro dia de parasitismo. O número de micro-esferas melanizadas, nas lagartas parasitadas, foi inferior mostrando uma melanização menos intensa. A análise ultra-estrutural comfirmou o efeito imunossupressor de $C$. flavipes para suprimir a resposta de encapsulação em $D$. flavipennella, pois, somente foi evidenciado à formação de cápsula de hemócitos, aderidas à superfície das micro-esferas, nas lagartas não parasitadas. Como efeito do parasitismo, foi registrado ainda no terceiro dia presença de hemócitos e células do corpo gorduroso em apoptose, além deste último apresentar aspecto de degeneração. Conclui-se que $C$. flavipes suprimi a resposta imunológica celular e humoral de D. flavipennella e afeta drasticamente o tecido gorduroso.

Palavras-chave: encapsulação, hemócitos, resposta humoral, parasitoide, broca da cana-de-açúcar (Diatraea saccharalis).

\section{REFERENCES}

ALLEYNE M AND WIEDENMANN RN. 2001. Encapsulation and total hemocyte numbers in three lepidopteran stemborers parasitized by Cotesia flavipes - complex endoparasitoids. Exp Appl 100: 279-293.

ARAÚJO JR, BOTELHO PSM, ARAÚJO SMSS, ALMEIDA LC AND DEGASPARI N. 1985. Nova dieta artificial para criação da Diatraea saccharalis (Fabr.). Saccharum APC. Rev Tecnol Indúst Açuc Alcool 36: 45-48.

ASGARI S. 2006. Venom proteins from the polydnavirus producing endoparasitoids: Their role in host-parasite interactions. Arch Insect Biochem 61: 146-156.

ASGARI S AND RIVERS DB. 2011. Venom proteins from endoparasitoid wasps and their role in host-parasite interactions. Annu Rev Entomol 56: 313-335.

ASHIDA M AND BREY PT. 1998. Recent advances in research an the insect prophenoloxidase cascade. In: BREY P and HULTMARK D (Eds), Molecular mechanisms of immune responses in insects, London: Chapman \& Hall, p. 135-172.

BAE S AND KIM Y. 2004. Host physiological changes due to parasitism of a braconid wasp, Cotesia plutellae, on diamondback moth, Plutella xylostella. Comp Biochem Physiol 138A: 39-44.

BeCKAGE NE. 1998. Parasitoids and polydnaviruses. BioScience 48: 305-311.

BECKAGE NE. 2006. Insect Immunology. In: SCHOWALTER TD. Insect Ecology: An ecosystem approach, San Diego: Academic Press, p. 243-270.

Beckage NE AND Gelman DB. 2004. Wasp parasitoid disruption of host development: Implications for new biologically based strategies for insect control. Annu Rev Entomol 49: 299-330.

BRADFORD MM. 1976. A rapid and sensitive method for the quantitation of microgram quantities of protein utilizing the principle of protein-dye binding. Anal Biochem 72: 248-254

CARTON Y AND NAPPI AJ. 1997. Drosophila cellular immunity against parasitoids. Parasit Today 13: 218-227. 
CARTON Y, NAPPI AJ AND POIRIÉ M. 2005. Genetics of antiparasite resistence in invertebrates. Develop \& Comp Immunol 29: 9-32.

Conte H, Vinson SB AND CRUZ-LANDim C. 1995. Ultrastructure of teratocytes in the hemolymph of Diatraea saccharalis (Lep.; Pyralidae) parasitized by Cotesia flavipes (Hym.; Braconidae). Acta Microsc 4: 154-154.

DAHLMAN DH AND VINSON SB. 1993. Teratocytes: developmental and biochemical characteristics. In: BECKAGE NE, THOMPSON SN AND FEDERICI BA (Eds), Parasites and pathogens of insects, San Diego: Academic Press, p. 145-165.

EDWARDS JP, WEAVER RJ AND MARRIS GC. 2001. Endocrine changes in lepidopteran larvae: Potencial challenges to parasitoid development and survival. In: EDWARDS JP AND WEAVER RJ (Eds), Endocrine Interactions of Insect Parasites and Pathogens, Oxford: BIOS Scientific Publishers, Oxford, UK, p. 1-32.

ER A, UÇKAN F, RIVERS DB AND SAK O. 2010. Cytotoxic effects of parasitism and application of venom from the endoparasitoid Pimpla turionellae on hemocytes of the host Galleria mellonella. J Appl Entomol 135: 225-236.

FALLEIROS AMF, BOMBONATO MTS AND GREGÓRIO EA. 2003. Ultrastructural and quantitative studies of hemocytes in the sugarcane borer, Diatraea saccharalis (Lepidoptera: Pyralidae). Braz Arch Biol Technol 46: 287-294.

FolEY PH AND O'FAREL FE. 2003. Nitric oxide contributes to induction of innate immune responses to gram-negative bacteria in Drosophila. Genes Devel 17: 115- 125.

Freitas MRT, FonseCA APP, Silva EL, MENDONÇA AL, Silva CE, Mendonça AL, Nascimento RR and SAnt'Ana AEG. 2006. The predominance of Diatraea flavipennella (Lepidoptera: Crambidae) in sugar cane fields in the state of Alagoas, Brazil. Fl Entomolt 89: 539-540.

HENSLEY SD AND HAMMOND JR AM. 1968. Laboratory technique for rearing the sugarcane borer on an artificial diet. J Econ Entomol 61: 1742-1743.

IBRAHIM AMA AND KIM Y. 2006. Parasitism by Cotesia plutellae alters the hemocyte population and immunological function of the diamondback moth Plutella xylostella. J Insect Physiol 52: 943-950.

LAVINE MD AND BeCKAGE NE. 1995. Polydnaviruses, potent mediators of host insect immune dysfunction. Parasitol Today 11: 368-378.

LAVINE MD AND STRAND MR. 2002. Insect hemocytes and their role in immunity. Insect Biochem Mol Biol 32: 1295-1309.

LING E AND YU XQ. 2006. Cellular encapsulation and melanization are enhanced by immulectins, pattern recognition receptors from the tobacco hornworm Manduca sexta. Dev Comp Immunol 30: 289-299.

LUO K AND PANG Y. 2006. Spodoptera litura multicapsid nucleopolyhedrovirus inhibits Microplitis bicoloratus polydnavirus-induced host granulocytes apoptosis. J Insect Physiol 52: 795-806.
MABIALA-Moundoungou ADN, Doury G, Eslin P, CHERQui A AND PRÉvost G. 2010. Deadly venom of Asobara japonica parasitoid needs ovarian antidote to regulate host physiology. J Insect Physiol 56: 35-41.

Mahmoud AMA, Luna-Santillana EJ, GuO X, ReyesVILlANUEVA F AND RodRÍGUEZ-PÉREZ MA. 2012. Development of the braconid wasp Cotesia flavipes in two Crambids, Diatraea accharalis and Eoreuma loftini: Evidence of host developmental disruption. J Asia Pac Entomol 15: 63-68.

MAHMOUd AMA, LunA-SANTILlAnA EJ AND RodRíGuEZPÉREZ MA. 2011. Parasitism by the endoparasitoid wasp Cotesia flavipes induces cellular immunosuppression and enhances the susceptibility of Diatraea saccharalis to Bacillus thuringenisis. J Insect Sci 11: 119.

MAPA - Ministério DA Agricultura, PECUÁRIA E Abastecimento. 2012. Cultura: Cana-de-açúcar. Fonte consultada: http://www.agricultura.gov.br/vegetal/culturas/ cana-de-acucar. Acessado em 11em novembro de 2012.

MENDONÇA AF. 1996. Guia das principais pragas da cana-deaçúcar. In: MENDONÇA AF (Ed), Pragas da cana-deaçúcar, Maceió: Insetos \& Cia, p. 3-48.

MÜller F, Ádori C AND SASS M. 2004. Autophagic and apoptotic features during programmed cell death in the fat body of the tobacco hornworm (Manduca sexta). Eur J Cell Biol 83: 67-78.

NAKAMATSU Y AND TANAKA T. 2003. Venom of ectoparasitoid, Euplectrus. sp. near plathypenae (Hymenoptera: Eulophidae) regulates the physiological state of Pseudaletia separate (Lepidoptera: Noctuidae) host as a food resource. J Insect Physiol 49: 149-159.

NAPPI AJ. 2010. Cellular immunity and pathogen strategies in combative interactions involving Drosophila hosts and their endoparasitic wasps. ISJ 7: 198-210.

NAPPI AJ, CARTON Y AND FREY F. 1991. Parasite-induced enhancement of hemolymph tyrosinase activity in a selected immune reactive strain of Drosophila melanogaster. Arch Insect Biochem Physiol 18: 159-168.

NAPPI AJ, CARTON Y, LI J AND VASS E. 1992. Reduced cellular immune competence of a temperature sensitive dopa decarboxylase mutant strain of Drosophila melanogaster against the parasite Leptopilina boulardi. Comp Biochem Physiol 101: 453-460.

NAPPI AJ AND OTTAVIANi E. 2000. Cytotoxicity and cytotoxic molecules in invertebrates. BioEssays 22: 469-480.

NAPPI AJ, VASS E, FREY F AND CARTON Y. 2000. Nitric oxide involvement in Drosophila immunity. Nitric Oxide Biol Ch 4: 423-430.

Pinto AS, Garcia JF And Botelho PSM. 2006. Controle biológico de pragas da cana-de-açúcar. In: PINTO AS, NAVA DE, ROSSI MM AND MALERBO-SOUZA DT (Eds), Controle biológico de pragas na prática, Piracicaba: FEALQ, p. 65-74.

RIBEIRO C AND BREHÉLIN M. 2006. Insect haemocytes: What type of cell is that? J Insect Physiol 52: 417-429. 
RICHARDS EH AND DANI MP. 2007. Venom-induced apoptosis of insect hemocytes. In: RIVERS DB AND YODER JA (Eds), Recent advances in the biochemistry, toxicity, and mode of action of parasitic wasp venoms, Kerala: Research SignPost, Kerala, India, p. 19-36.

RIVERS DB, ERGIN E AND UÇKAN F. 2007. Cell death in the host-parasitoid relationship. In: CORVIN AJ (Ed), New developments in cell apoptosis research, New York: Nova Science Publishers, New York, USA, p. 69-96.

Rodríguez-PÉrez MA, DUMPIT RF, LENZ JM, POWELl EN, TAM SY AND BECKAGE NE. 2005. Host refractoriness of the tobacco hornworm, Manduca sexta, to the braconid endoparasitoid Cotesia flavipes. Arch Insect Biochem Physiol 60: 159-71.

SAss M, KISS A AND LOCKE M. 1994. Integument and hemocyte peptides. J Insect Physiol 40: 407-421.

Silva CCM, Marques EJ, OliveIRA JV AND VALENTE ECN 2012. Preference of the parasitoid Cotesia flavipes (Cam.) (Hymenoptera: Braconidae) for Diatraea (Lepidoptera: Crambidae). Acta Sci Agronomy 34: 23-27.
STRAND MR AND PECH LL. 1995. Immunological basic for compatibility in parasitoid-host relationships. Annu Rev Entomol 40: 31-56.

SUZUKI M AND TANAKA T. 2006. Virus-like particles in venom of Meteorus pulchricornis induce host hemocyte apoptosis. J Insect Physiol 52: 602-611.

TERAMOTO T. AND TANAKA T. 2004. Mechanism of reduction in the number of the circulating hemocytes in the Pseudaletia separata host parasitized by Cotesia kariyai. J Insect Physiol 50: 1103-1111.

Zhang Z, Ye G, CAI J AND Hu C. 2005. Comparative venom toxicity between Pteromalus puparum and Nasonia vitripennis (Hymenoptera: Pteromalidae) toward the hemocytes of their natural hosts, non-target insects and cultured insect cells. Toxicon 46: 337-349. 